\title{
Capability of selected mushrooms to biodegrade polyethylene
}

\author{
Nwogu NA ${ }^{1,2^{*}}$, Atuanya EI ${ }^{1}$ and Akpaja ${ }^{3}$ EO \\ ${ }^{1}$ Department of Microbiology, University of Benin, P. M. B. 1154, Benin City, Edo State, Nigeria \\ ${ }^{2}$ Nigerian Institute for Oceanography and Marine Research, P.M.B. 4015, Sapele, Delta State, Nigeria. \\ ${ }^{3}$ Department of Plant Biology and Biotechnology, University of Benin, P. M. B. 1154, Benin City, Edo State, Nigeria.
}

Nwogu NA, Atuanya EI, Akpaja EO 2012 - Capability of selected mushrooms to biodegrade polyethylene. Mycosphere 3(4), 455-462, Doi 10.5943/mycosphere/3/4/9

Many natural polymers are susceptible to microbial attack but synthetic polymers such as highmolecular weight polyethylene are generally difficult to degrade by microorganisms. Environmental concerns have led us to seek ways to resolve the problem that recalcitrant plastics pose on the ecology. The biodegradability of polyethylene films by selected exotic mushrooms was examined. In screening for the best polyethylene degrading-fungus, Pleurotus tuber-regium grew fastest on mineral salt medium containing polyethylene powder as sole carbon and energy followed by $P$. pulmonarius. Lentinus squarrosulus and Rigidoporus lignosus grew least on the medium. Degradation of polyethylene by $P$. tuber-regium and $P$. pulmonarius was determined by weight loss of sample and chemical changes measured by Fourier transform infra-red (FTIR) spectroscopy. Polyethylene biodegraded by $P$. tuber-regium and $P$. pulmonarius gave weight losses of $13.26 \%$ and 9.67\% respectively. FTIR analysis showed additional absorbance at regions corresponding to carbonyl groups in the spectra of polyethylene biodegraded by $P$. tuber-regium and P. pulmonarius, suggesting that polyethylene was degraded oxidatively. The enzyme assays showed that Manganese peroxidase $(\mathrm{MnP})$ may be the main enzyme involved in polyethylene degradation. These results suggest the capability of $P$. tuber-regium and $P$. pulmonarius to degrade polyethylene.

Key words - White-rot fungi - biodegradation - ligninolytic enzymes - polymer

\section{Article Information}

Received 5 July 2012

Accepted 23 July 2012

Published online 18 August 2012

*Corresponding author: Nwogu NA - e-mail - nwogunkem@yahoo.com

\section{Introduction}

A of the major environmental problem facing the world today is the contamination of soil, air and marine habitats by toxic chemicals from plastics. Synthetic polymers, such as polyethylene, are generally difficult to degrade by microorganisms. Research on the use of biological treatment has focused on bacteria, with fungal bioremediation (mycoremediation) attracting interest just within the past two decades (Lamar \& White 2007).

Although lignin is a natural polymer, and major component of woody plants, it is extremely resistant to attack by most microorganisms. At present, ligninolytic fungi are the most effective lignin degrading organisms (Wong 2009). There are numerous species of ligninolytic mushrooms in Nigeria (Okhuoya et al. 2010). Pleurotus tuber-reguim, a basidiomycete species, is found in many tropical countries in Africa and the Australasian-Pacific regions of the world. This mushroom grows on decaying wood in the forest, producing tuberous sclerotia that can be $25 \mathrm{~cm}$ or more in diameter and can later germinate to produce sporophores under appropriate climatic conditions (Isikhuemhen et al. 2003). Lentinus squarrrosulus and Pleurotus pulmonarius are two cultivated edible mushrooms, which can be also exploited for their lignin-degrading properties (Wuyep et al. 2003). 


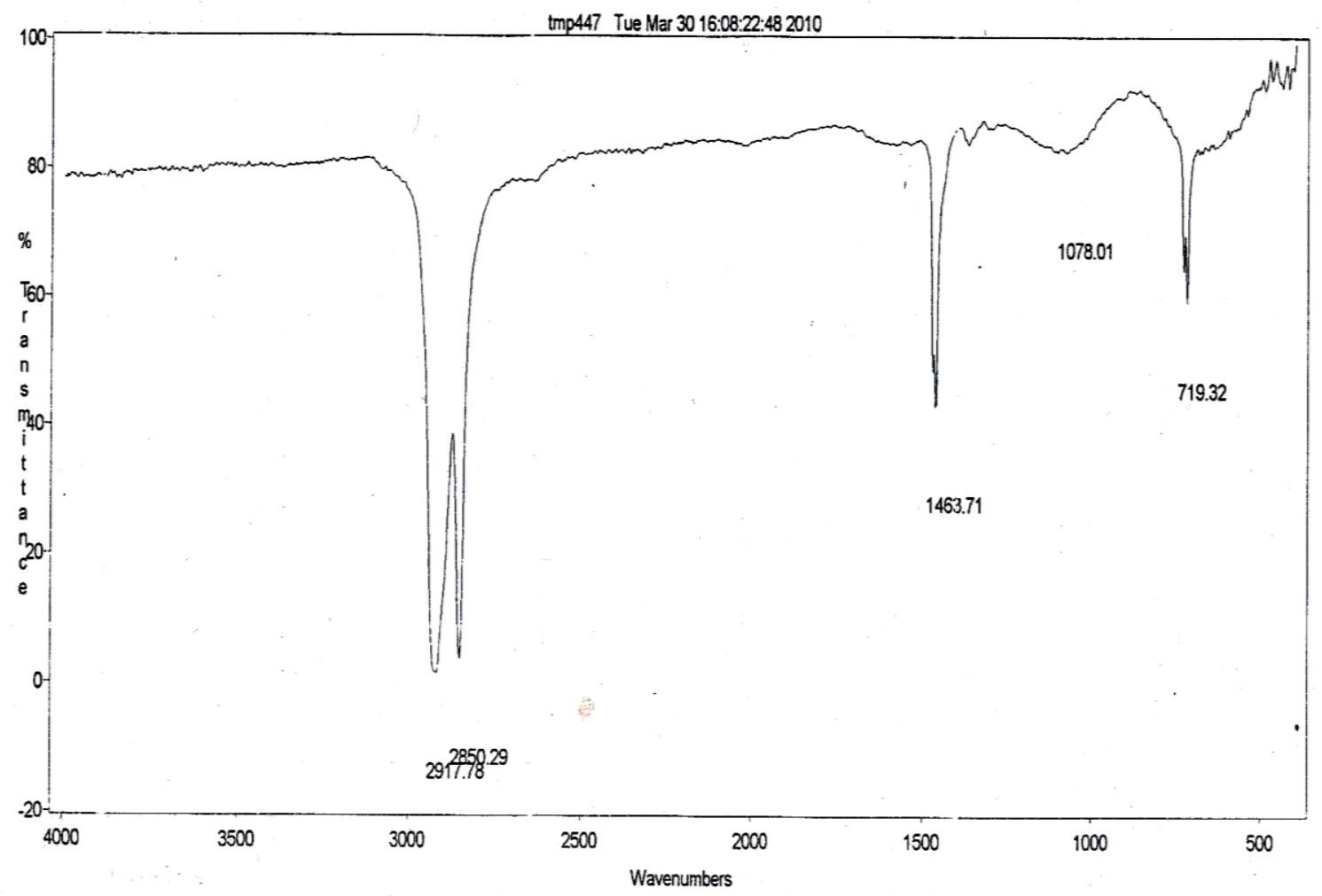

Fig. 1 - FTIR spectrum of undegraded polyethylene

The present study seeks to investigate the capability selected mushrooms to biodegrade polyethylene film.

\section{Methods}

\section{Source of Mushroom Cultures}

The monocultures of Lentinus squarrosulus, Pleurotus tuber-regium, $P$. pulmonarius and Rigidoporus lignosus used in this study were obtained from the Mushroom Science Unit of Department of Plant Biology and Biotechnology, University of Benin, Benin City, Edo State, Nigeria. The fungal strains were maintained on potato dextrose agar (PDA) slants. New PDA (Lab M, United Kingdom) plates were inoculated with the fungal strains and precultured for about 7 days at ambient temperature $\left(26 \pm 2^{\mathrm{O}} \mathrm{C}\right)$.

\section{Chemicals}

High molecular weight polyethylene powder and strips $(1 \mathrm{x} 4 \mathrm{~cm})$ were produced by Indorama, Eleme Petrochemical Company, Port Harcourt, Nigeria. Other chemicals and reagents were of analytical grade and were purchased from Zayo-Sigma Chemicals, Am Schlengerbush 22, 33106 Paderborn-Germany.

\section{Solid test medium}

In a preliminary experiment, the polyethylene degrading capabilities of the mushrooms were investigated on agar plates. A mineral salt medium was prepared according to the method described by Liyoshi et al. (1998) with minor modifications and composed of the following (per litre): $3 \mathrm{~g}$ suspended polyethylene powder, $20 \mathrm{~g}$ agar-agar, antibiotics, $1.0 \mathrm{~g}\left(\mathrm{NH}_{4}\right) \mathrm{H}_{2} \mathrm{PO}_{4}, 1.0 \mathrm{~g} \mathrm{KH}_{2} \mathrm{PO}_{4}$, $0.2 \mathrm{~g} \mathrm{NaH}_{2} \mathrm{PO}_{4}, 0.5 \mathrm{~g} \mathrm{MgSO}_{4} .7 \mathrm{H}_{2} \mathrm{O}$ and trace amount of $\mathrm{ZnSO}_{4}, \mathrm{CuSO}_{4}, \mathrm{MnSO}_{4}$.

\section{Plate inoculation and measurement of mycelial diameter.}

Uniform mycelia discs $(5 \mathrm{~mm}$ in diameter) were obtained from the growing edge of 7 day-old PDA cultures depending on the state of growth of the fungus, using a sterile cork borer. The discs were introduced (one each) into Petri-dishes of the mineral salt medium. The controls contained the different fungal inoculums grown on the same medium except polyethylene powder which was not added to the medium. The plates were sealed with paraffin film and incubated at room temperature $\left(26 \pm 2^{\mathrm{O}} \mathrm{C}\right)$ for 10 days. Measurement of the radial growth was made by 


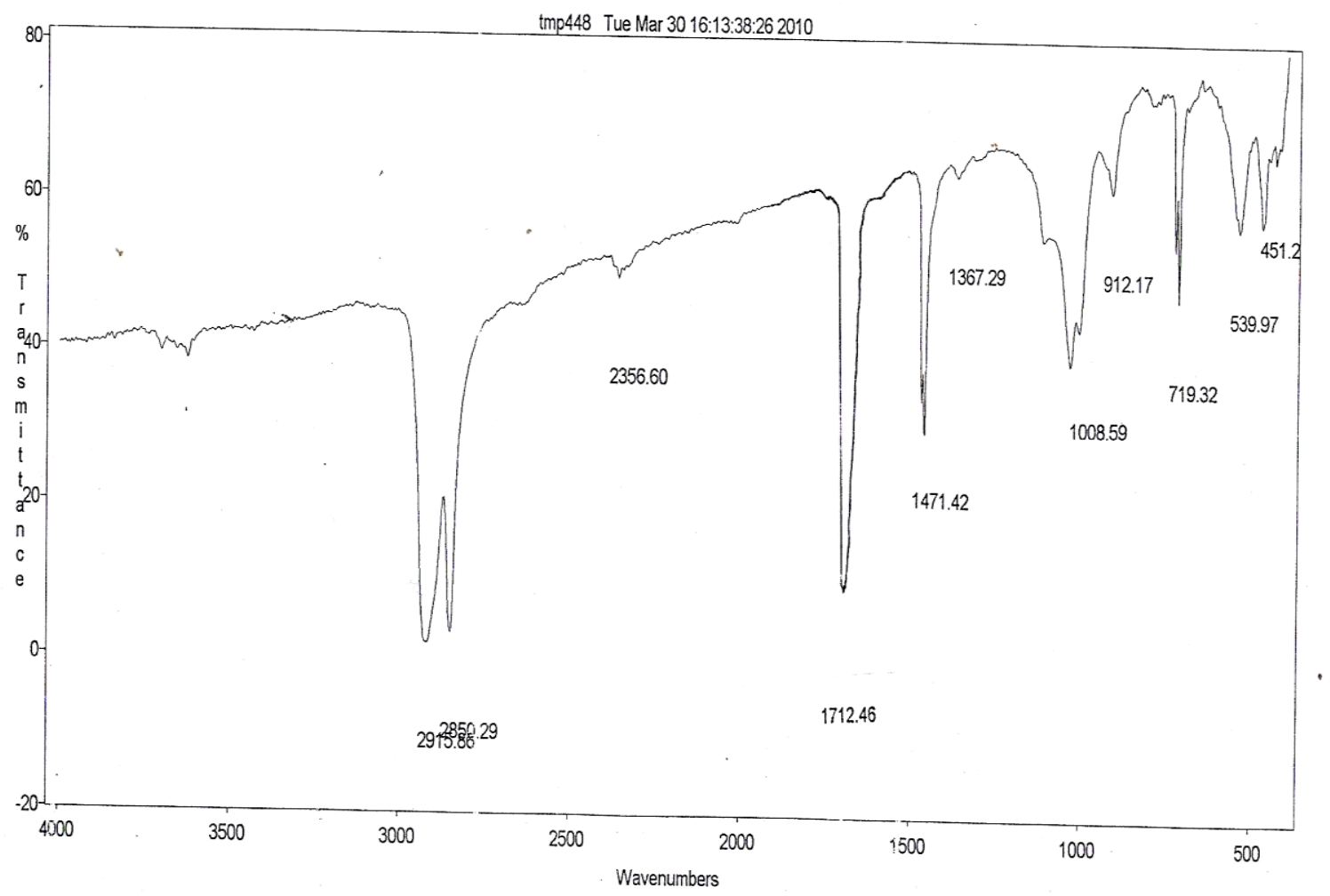

Fig. 2 - FTIR spectrum of polyethylene degraded by Pleurotus tuber-regium

drawing two lines which intersect at right angle on the centre of the underside of the $13 \mathrm{~cm}$ Petri dishes. Readings were taken at 24 hourly intervals from the second day after inoculation by measuring the diameter of the culture along the lines with a transparent ruler. The experiment was carried out in 5 replicates. After 10 days of incubation, mycelia biomass was determined according to the method of Okwulehie et al. (2006).

\section{Treatment of polyethylene film with mushrooms}

Each of two discs $(5 \mathrm{~mm})$ punched from the growing edge of the 7-days-old culture were placed on opposite sides of the mineral salt medium containing the same composition as the medium used for screening except polyethylene powder which was not added. After the inoculated medium was incubated for about 7 days at ambient temperature $\left(26 \pm 2^{\mathrm{O}} \mathrm{C}\right)$, a preweighed sterilized polyethylene strip $(1 \times 4 \mathrm{~cm})$ was placed on the grown mycelium and incubated at room temperature $\left(26 \pm 2^{\mathrm{O}} \mathrm{C}\right)$ for 40 days. Harvesting of the polyethylene films was carried out under sterilized conditions with the aid of sterilized forceps followed by washing in
$70 \%$ ethanol to remove as much cell mass from the residual film as possible, and dried at $45^{\circ} \mathrm{C}$ for 24 hours. The polyethylene membranes were allowed to equilibrate to ambient temperature for 24 hours before analysis

\section{Weight loss and chemical changes measurements}

The mass of each polyethylene sample was measured before and after degradation using a Mettler Toledo analytical balance, model AG 240. The breakdown of polyethylene polymer chain and presence of oxidation products of polyethylene during the experiment were evaluated by changes in the membrane's infra-red spectra measured by Fourier transform infrared (FTIR) spectroscopy (Genesis II FTIR, Mattson).

\section{Enzyme activity assays}

The agar media with mycelia were homogenized using a mortar and pestle at $4{ }^{\mathrm{O}} \mathrm{C}$ and centrifuged for 20 minutes at 3,000 rpm. The agar was immediately filtered off and absorbance of filtrate (source of enzymes) and substrate was monitored using Spectrumlab 23A spectrophotometer according to the method described by Niladevi \& Prema (2005). 
Table 1 Mycelial diameters $(\mathrm{cm})$ of mushrooms on mineral salt medium with polyethylene powder as sole carbon and energy sources.

\begin{tabular}{|c|c|c|c|c|c|c|c|c|c|c|}
\hline \multirow{2}{*}{ Mushrooms } & \multicolumn{10}{|c|}{ Treatment time (days) } \\
\hline & 1 & 2 & 3 & 4 & 5 & 6 & 7 & 8 & 9 & 10 \\
\hline P. tuberregium & $0.76 \pm 0.02 *$ & $1.08 \pm 0.03$ & $1.56 \pm 0.08$ & $2.20 \pm 0.06$ & $2.74 \pm 0.09$ & $3.22 \pm 0.23$ & $4.23 \pm 0.11$ & $4.67 \pm 0.21$ & $5.44 \pm 0.15$ & $6.36^{\mathrm{b}} \pm 0.15$ \\
\hline L. squarrosulus & $0.00 \pm 0.00$ & $0.00 \pm 0.00$ & $0.65 \pm 0.03$ & $0.97 \pm 0.04$ & $1.10 \pm 0.08$ & $1.10 \pm 0.08$ & $1.10 \pm 0.08$ & $1.10 \pm 0.08$ & $1.10 \pm 0.08$ & $1.10^{\mathrm{a}} \pm 0.08$ \\
\hline P. pulmonarius & $0.68 \pm 0.02$ & $1.03 \pm 0.06$ & $1.41 \pm 0.10$ & $1.96 \pm 0.13$ & $2.49 \pm 0.05$ & $2.73 \pm 0.05$ & $3.33 \pm 0.08$ & $4.25 \pm 0.19$ & $5.15 \pm 0.21$ & $5.77^{\mathrm{b}} \pm 0.21$ \\
\hline R. lignosus & $0.00 \pm 0.00$ & $0.00 \pm 0.00$ & $0.00 \pm 0.00$ & $0.64 \pm 0.02$ & $0.67 \pm 0.03$ & $0.74 \pm 0.04$ & $0.80 \pm 0.06$ & $0.80 \pm 0.06$ & $0.80 \pm 0.06$ & $0.80^{\mathrm{a}} \pm 0.06$ \\
\hline
\end{tabular}

$*=$ Means of five replicates \pm Standard error. Mean values followed by the same letters are not significantly different $(\mathrm{P}<0.001)$ according to LSD test

Table 2 Mycelia biomass of Pleurotus tuber-regium and P. pulmonarius

\begin{tabular}{llcc}
\hline \multirow{2}{*}{ Organisms } & \multicolumn{2}{c}{ Weight of mycelium } & Moisture Content \\
& Wet weight $(\mathrm{g})$ & Dry weight $(\mathrm{g})$ & $(\%)$ \\
\hline P. tuber-regium & $1.5116 \pm 0.1825^{*}$ & $0.0725 \pm 0.0059$ & 95.2038 \\
$P$. pulmonarius & $0.7581 \pm 0.0297$ & $0.0451 \pm 0.0954$ & 94.0509 \\
\hline
\end{tabular}

$*=$ Means of five replicates \pm Standard error. 


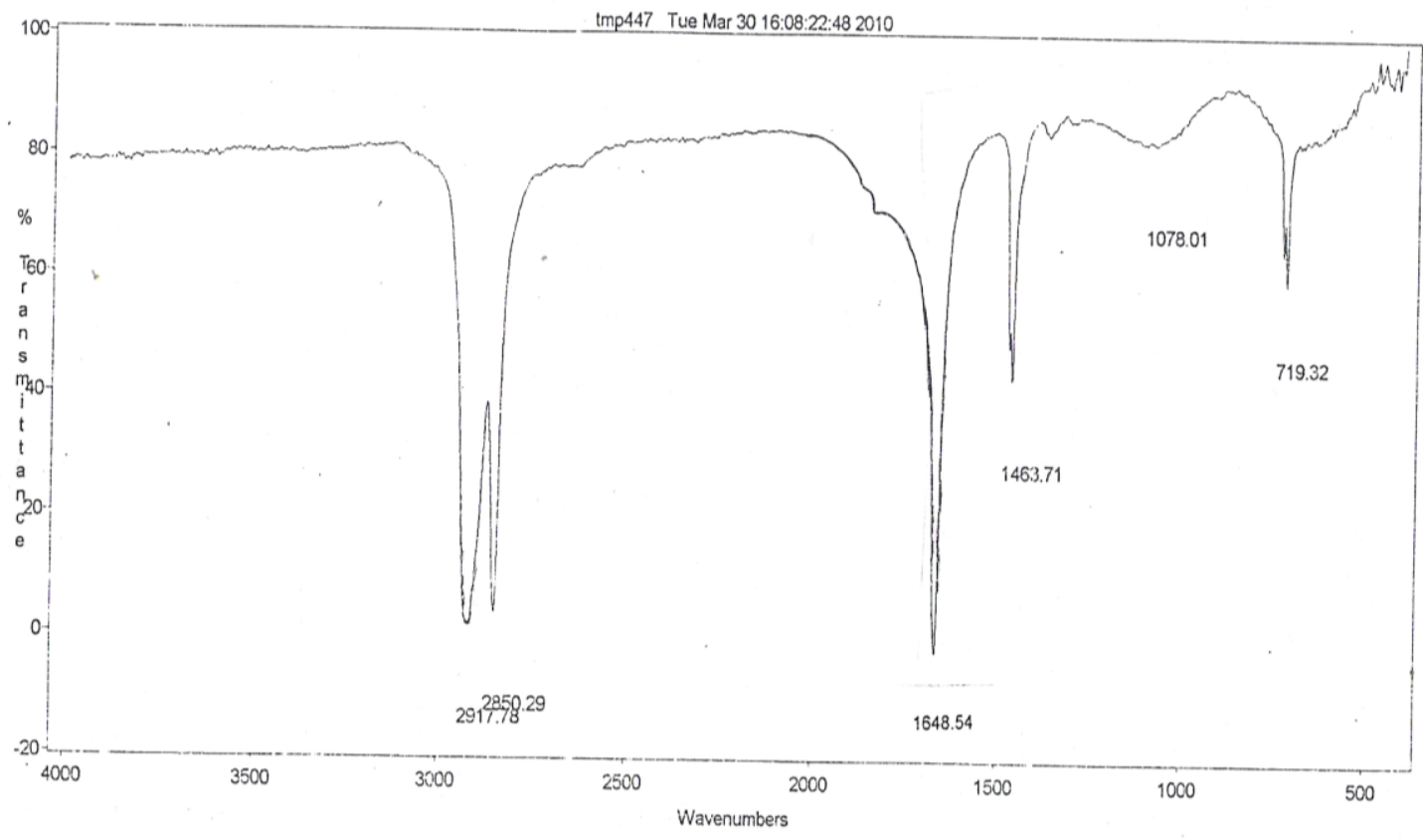

Fig. 3 - FTIR spectrum of polyethylene degraded by Pleurotus pulmonarius

\section{Statistical analysis}

The data obtained from the experiments were subjected to ANOVA, while the means were separated using the Least Significant Difference (LSD) test.

\section{Results and discussion}

The growth of the four mushrooms on mineral salt medium with polyethylene powder as sole carbon and energy sources are presented in Table 1. Pleurotus tuber-regium grew fastest on the medium with mycelia growth of $6.36 \pm 0.15 \mathrm{~cm}$. This was followed closely by $P$. pulmonarius $(5.77 \pm 0.21 \mathrm{~cm})$. Lentinus squarrosulus $(1.10 \pm 0.80 \mathrm{~cm})$ and Rigidoporus lignosus $(0.80 \pm 0.06 \mathrm{~cm})$ showed the least growth. There was no measurable mycelia growth on the controls. The performance of the mushrooms varied highly significantly $(\mathrm{p}<0.001)$. However, there was no significant difference $(\mathrm{p}>0.001)$ between the mycelia growth of $P$. tuber-regium and $P$. pulmonarius. The wet and dry weight of $P$. tuber-regium and $P$. pulmonarius is shown in Table 2. P. tuber-regium and $P$. pulmonarius had a dry weight of $0.0725 \pm 0.0039 \mathrm{~g}$ and $0.0451 \pm 0.0045 \mathrm{~g}$, respectively. The biomass of L. squarrosulus and $R$. lignosus were not determined since there were no significant mycelia growths on the medium. Fungal mycelia growth was used as the parameter for the screening of polyethylene degrading whiterot fungi in the preliminary experiment. The outstanding mycelia growth of Pleurotus tuberregium and $P$. pulmonarius on the mineral salt medium containing polyethylene powder as sole carbon and energy sources (Table 1) may be due to higher production of extracellular enzymes that enabled them to utilize the polyethylene powder as carbon and energy sources faster than the other two mushrooms. Although it is known that all white-rot fungi produce extracellular enzymes (Wong 2009), Pleurotus species seem to be more aggressive as shown in their ability to thrive on the mineral salt medium. These results confirm the findings of Okwulehie et al. (2006) that Pleurotus species are able to utilize differeent carbon sources for growth.

Polyethylene strips incubated on $P$. tuber-regium showed weight loss of $13.26 \%$ while polyethylene strips degraded by $P$. pulmonarius showed $9.67 \%$ weight loss. No detectable change in weight was obtained in the polyethylene strip grown in the control medium (Table 3). Therefore, the observed percentage weight loss of polyethylene strips incubated on the different mushrooms was not as result of chemicals in the mineral salt medium but because of a biological process. 


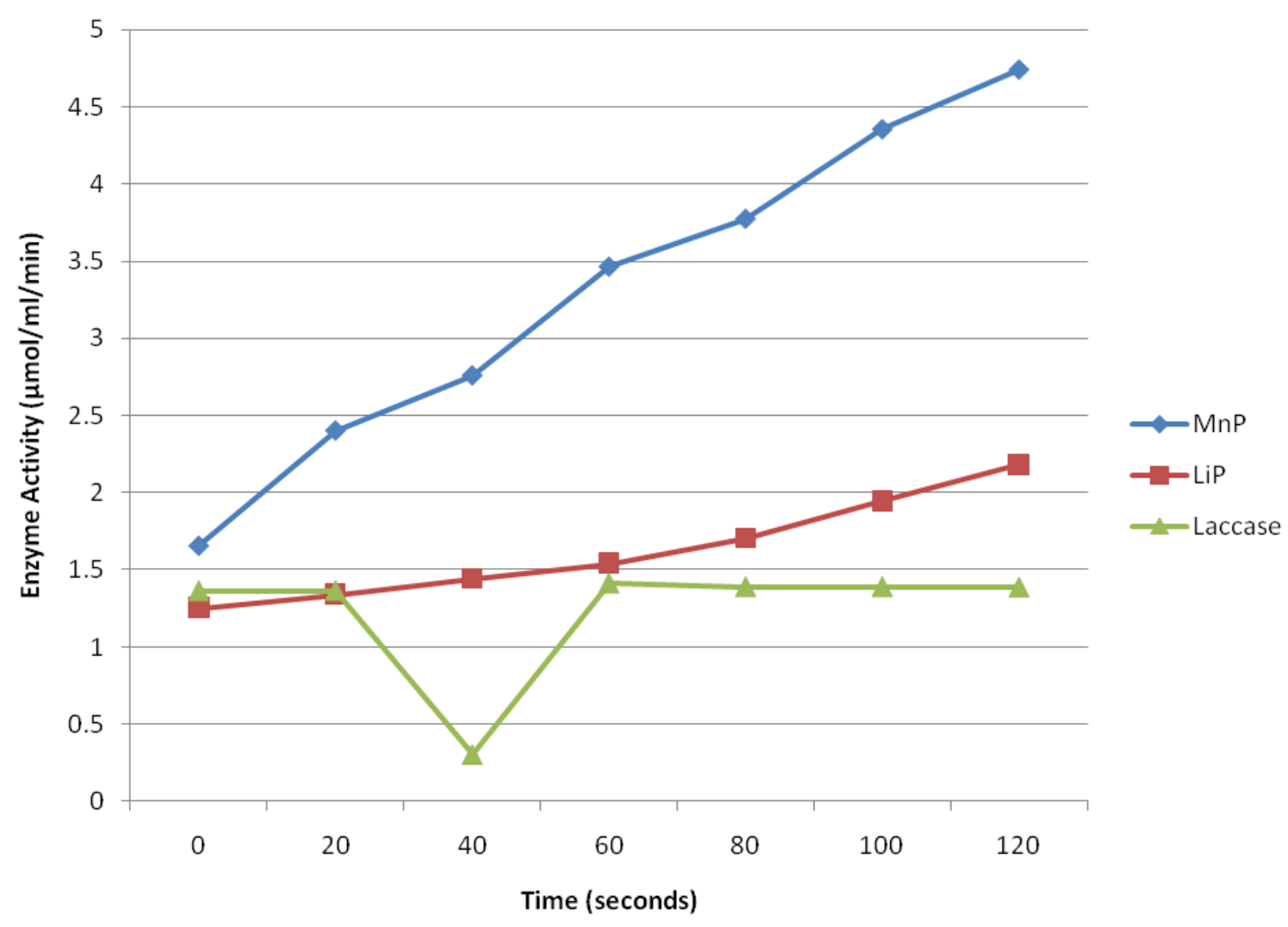

Fig. 4 - Enzyme activity of MnP, LiP, and laccase produced by Pleurotus tuber-regium

Hence, the observed percentage weight loss could be due to an oxidation process which is comparable to the findings of Grimma et al. (2000) who reported that in polymer degradation, the mechanisms are typically biological hydrolysis and oxidation. The reduction in mean weight was an indication that degradation of polyethylene has taken place.

FTIR analysis of undegraded polyethylene showed absorbance at 2917.78 $\mathrm{cm}^{-1}, 2850.29 \mathrm{~cm}^{-1}, 1463.71 \mathrm{~cm}^{-1}$, and 719.32 $\mathrm{cm}^{-1}$, (Fig. 1). Polyethylene degraded by $P$. tuber-regium showed additional absorbance at $1712.46 \mathrm{~cm}^{-1}$ (Fig. 2). Similarly, additional absorbance at $1648.54 \mathrm{~cm}^{-1}$ was observed in the spectrum of polyethylene strips incubated on $P$. pulmonarius (Fig. 3). Absorbance at 2850 to $3000 \mathrm{~cm}^{-1}$ region corresponds to the alkyl groups $\left(\mathrm{CH}_{3} \mathrm{CH}_{2}, \mathrm{CH}\right)$. These features are typical of undegraded high density polyethylene (HDPE). Besides the alkyl groups at 2850 to $3000 \mathrm{~cm}^{-1}$ and 1415 to $1465 \mathrm{~cm}^{-1}$, polyethylene treated with $P$. tuber-regium gave additional absorbance at bands $1710-1715 \mathrm{~cm}^{-1}$ (Fig. 2). The region of increased peak absorbance (1710-1715 $\left.\mathrm{cm}^{-1}\right)$ of the FTIR spectrum correlates with carbonyl compounds including esters, aldehydes and carboxylic acids (Agamuthu et al. 2005). This feature is an indication of various types of oxidation products formed during the biodegradation of polyethylene film. This observation shows that polyethylene was degraded oxidatively by the mushroom, $P$. tuber-regium. Orhan \& Büyükgüngör (2000) also recorded similar results when polyethylene samples were exposed to soil inoculated with white-rot fungus Phanerochaete chrysosporum. In the FTIR spectrum of polyethylene biodegraded by $P$. pulmonarius, strong absorbance in the region of $1650-1860 \mathrm{~cm}^{-1}$ (Fig. 3) is due to carbonyl compounds. This is attributed to oxidation of polyethylene by the enzymes. Yamada-Onodera et al. (2001) reported formation of bands at $1620-1640 \mathrm{~cm}^{-1}$ and $840-880 \mathrm{~cm}^{-1}$ attributed to oxidation of polyethylene. Thus, the FTIR spectra of polyethylene biodegraded by $P$. tuber-regium and $P$. pulmonarius gave conclusive evidence of the oxidation of polyethylene with the addition of carbonyl group in their spectra. 


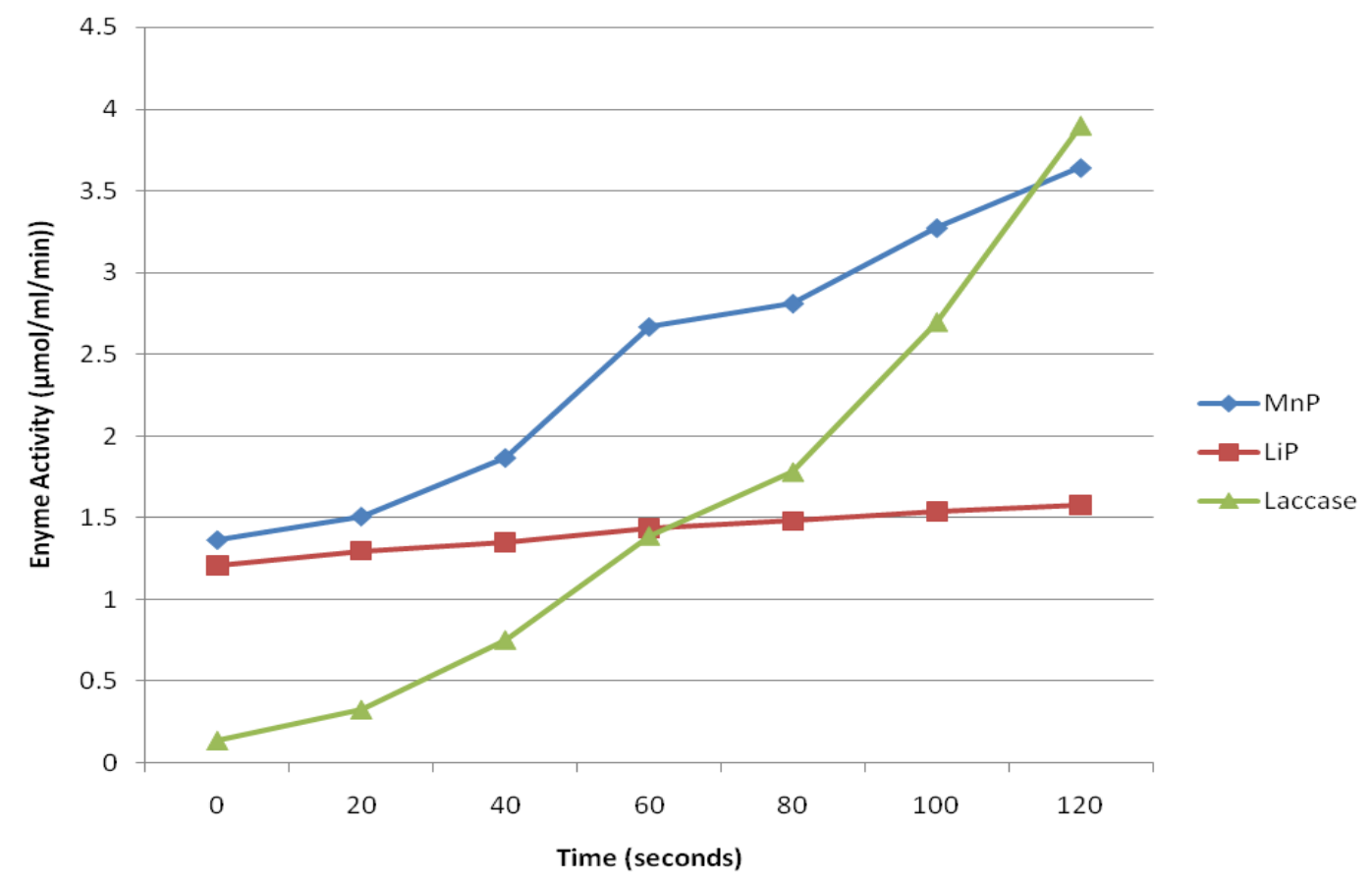

Fig. 5 - Enzyme activity of MnP, LiP, and laccase produced by Pleurotus pulmonarius

Manganese peroxidase (MnP), lignin peroxidase $(\mathrm{LiP})$ and laccase enzyme activities produced by $P$. tuber-regium and $P$. pulmonarius during incubation on polyethylene strip are shown (Figs. 4, 5). Both mushrooms produced MnP, LiP, and laccase enzymes. The MnP activity produced by $P$. tuber-regium was significantly higher than LiP and laccase activities (Fig. 4). This result suggests that $\mathrm{MnP}$ may be the main enzyme involved in polyethylene degradation. On the other hand, laccase activities produced by $P$. pulmonarius were higher than MnP and LiP activity (Fig. 5). This result shows that laccase enzyme may also play a role in polyethylene degradation. The purification and characterization of the enzyme(s) catalyzing polyethylene degradation are currently under study.

\section{Conclusion}

Synthetic polymers such as high density polyethylene are generally difficult to degrade by microorganisms and their use in the production of disposable or packaging materials pose dangerous environmental problems. However, this study shows the ability of some mushrooms to degrade polyethylene. The weigh losses and FTIR spectra of degraded polyethylene gave conclusive evidence for polyethylene degradation by these mushrooms.

Table 3 Effects of Pleurotus tuber-regium and $P$. pulmonarius on the biodegradation of polyethylene film

\begin{tabular}{lccc}
\hline \multirow{2}{*}{ Organisms } & \multicolumn{2}{c}{ Weight of Polyethylene Strips } & Weight Loss \\
\cline { 2 - 3 } & $\begin{array}{c}\text { Weight before } \\
\text { inoculation }(\mathrm{g})\end{array}$ & $\begin{array}{c}\text { Weight after inoculation } \\
(\mathrm{g})\end{array}$ & \begin{tabular}{c} 
W $)$ \\
\hline$P$. tuber-regium
\end{tabular} \\
\hline P. pulmonarius & $0.0163 \pm 0.0020^{*}$ & $0.0142 \pm 0.0018$ & 13.2582 \\
Control & $0.0163 \pm 0.0020$ & $0.0147 \pm 0.0019$ & 9.6732 \\
\hline
\end{tabular}

$*=$ Means of five replicates \pm Standard error. 


\section{References}

Agamuthu P, Faizura NP. 2005 Biodegradability of degradable plastics waste. Waste Management and Research 23, 95-100.

Grimma S, Bellon-Maurel V, Feuilloley P, Silvestre F. 2000 - Aerobic biodegradation of polymers in solid state conditions: a review of environmental and physicochemical parameter settings in laboratory simulations. Journal of Polymer and Environment 8, 183-195.

Isikhuemhen OS, Anoliefo GO, Oghale OI. 2003 - Bioremediation of crude oil polluted soil by the white rot fungus, Pleurotus tuberregium (Fr.) Sing. Environmental Science \& Pollution Research 10, $108-112$.

Lamar RT, White RB. 2007 - Current progress in the application of mycoremediation to soil clean up. In Hurst, G. L., Crawford, R. L, Garland, J. L., Lipson, D. A., Mills, A. L. and Stetzenband, L. D. (eds.). Manual of Environmental Microbiology $\left(3^{\text {rd }}\right.$ edition). ASM Press. Washington, D.C. pp1097 - 1106.

Liyoshi Y, Tsutsumi Y, Nishida T. 1998 Polyethylene degradation by lignindegrading fungi and manganese peroxidase. Journal of Wood Science 44, 222-229.

Niladevi KN, Prema P. 2005 - Mangrove actinomycetes as the source of ligninolytic enzymes. Actinomycetologica 19, 40- 47.
Okhuoya JA, Akpaja EO, Osemwegie OO, Oghenekaro AO, Ihayere CA. 2010 Nigerian Mushrooms: underutilized nonwood forest resources. Journal of Applied Science and Environmental Management 14 (1), 43- 54.

Okwulehie IC, Okwujiako IA, Igbojionu V. 2006 - Studies on nutritional requirement and growth of Pleurotus pulmoarius (Fries) Quelet, an exotic mushroom. Nigerian Journal of Botany 19 (2), 308316.

Orhan Y, Büyükgüngör H. 2000 Enhancement of biodegradability of disposal polyethylene in controlled biological soil. International Journal of Biodeterioration and Biodegradation 45, 49-55.

Wong DWS. 2009 - Structure and action mechanism of ligninolytic enzymes. Applied Journal of Biochemistry and Biotechnology 157, $174-209$.

Wuyep PA, Khan AU, Nok AJ. 2003 Production and regulation of lignin degrading enzymes from Lentinus squrrosulus (Mont.) Singer and Psathyrella atroumbonata Pegler. African Journal of Biotchnology 2(11), 444- 447.

Yamada-Onodera K, Mukumoto H, Katsuyaya Y, Saiganji A, Tani Y. 2001 Degradation of polyethylene by a fungus, Penicillium simplicissimum YK. Polymer Degradation and Stability 72, 323 - 327. 